A N N A L E S

UNIVER S T ATIS M A R A E C URIE-SKŁODOW K A

LUBLIN - POLONIA

VOL. XXXIII, 2

SECTIO J

2020

Uniwersytet Marii Curie-Skłodowskiej w Lublinie. Wydział Pedagogiki i Psychologii

\title{
ANNA BŁASZCZAK
}

ORCID: 0000-0003-0597-5117

anna.blaszczak@umcs.lublin.pl

\section{Znaczenie intelektualnych i osobowościowych korelatów osiagnięć szkolnych}

The Significance of Intellectual and Personality Correlates of Academic Achievements

Propozycja CYTOWANIA: Błaszczak, A. (2020). Znaczenie intelektualnych i osobowościowych korelatów osiągnięć szkolnych. Annales Universitatis Mariae Curie-Skłodowska. Sectio J, Paedagogia-Psychologia, 33(2), 25-34. DOI: http://dx.doi.org/10.17951/j.2020.33.2.25-34.

\section{STRESZCZENIE}

W artykule omówiono zagadnienie intelektualnych i osobowościowych uwarunkowań sukcesów szkolnych i wyników egzaminacyjnych. Analizie poddano argumenty na rzecz tezy, że zdolności poznawcze warunkują osiągnięcia szkolne. W efekcie podjętych rozważań sformułowano wniosek, że inteligencja stanowi potencjał, którego znaczenie zależy od etapu edukacyjnego - mocniej koreluje z osiągnięciami szkolnymi we wczesnych etapach kształcenia. Na wyższych poziomach edukacji istotniejszy jest nie sam poziom inteligencji ogólnej, lecz specyficzne zdolności poznawcze i ich dopasowanie do wymagań zadania. Co więcej, realizacja potencjału poznawczego w postaci wysokich wyników akademickich nie jest dana sama z siebie oraz wymaga pracy i wytrwałości. Zależy więc od czynników osobowościowych, w tym przede wszystkim od sumienności uwzględnionej w modelu tzw. Wielkiej Piątki.

Słowa kluczowe: inteligencja; osobowość; Wielka Piątka; sumienność; osiągnięcia szkolne

\section{WPROWADZENIE}

„Wszyscy liczą IQ. Ale czy IQ się liczy?” - tymi słowami, parafrazując Sternberga, Edward Nęcka (2012) rozpoczął jeden ze swoich wykładów, zabierając tym samym głos w obecnej w literaturze przedmiotu dyskusji nad znaczeniem inteligencji w życiu człowieka. A jeśli nie IQ, to co? - można by było pójść o krok dalej w stawianiu pytań. Trudno jednak choćby przybliżyć się do odpowiedzi na 
to pytanie bez dookreślenia obszaru naszego funkcjonowania, którego wpływy te miałyby dotyczyć. W niniejszym opracowaniu refleksji poddano znaczenie inteligencji oraz czynników osobowościowych dla osiągnięć szkolnych: ocen, sprawnej realizacji zadań edukacyjnych czy wyników egzaminów.

Zagadnienie czynników psychologicznych determinujących sukcesy edukacyjne od lat intryguje psychologów (por. Kossowska, 2004; Boryszewska, 2008). Wysokie oceny w szkole oraz wyniki egzaminacyjne mają znaczenie dla kariery edukacyjnej młodego człowieka, umożliwiają mu dostanie się do prestiżowego liceum, wybór wymarzonej uczelni czy uzyskanie stypendium. Ze względu na niezwykłą wagę tego zagadnienia istotne stało się określenie, która ze zmiennych psychologicznych jest najbardziej znaczącą właściwością determinującą sukcesy edukacyjne. Najczęściej w badaniach koncentrowano się na roli inteligencji oraz czynników osobowościowych jako podstawowych determinantach powodzeń lub niepowodzeń w nauce. Jednak zbierane przez psychologów dane rzadko jednoznacznie wskazują na którąkolwiek z tych cech. Celem opracowania jest przegląd literatury naukowej poświęconej znaczeniu inteligencji oraz osobowości dla osiągnięć szkolnych. Przeprowadzona tu analiza argumentów i danych obecnych we wcześniejszych pracach ma przybliżyć do odpowiedzi na pytanie o rolę zdolności poznawczych oraz cech osobowości dla sukcesów edukacyjnych.

\section{INTELIGENCJA}

W świetle analiz polskich i zagranicznych, prowadzonych przez Małgorzatę Kossowską i Hanry'ego Schouwenburga (2000), to właśnie inteligencja, rozumiana jako zdolność do dostosowywania się do kontekstu, obejmująca radzenie sobie z sytuacjami nowymi (Sternberg, 1985), ma decydować o poziomie kompetencji szkolnych (por. Sternberg, 2001). Według tych badaczy skuteczne wykonywanie zadań szkolnych jest także funkcją sprawnego nabywania i wykorzystywania wiedzy (Kossowska, Schouwenburg, 2000). Zdolność ta składa się z trzech głównych komponentów determinujących efekty działań jednostki, w tym jej sukcesy szkolne. Są to: 1) selektywne kodowanie, rozumiane jako skuteczne wybieranie informacji ważnych spośród tych nieistotnych dla zadania; 2) selektywne kombinowanie, a więc łączenie wcześniej przesianych informacji w większe, sensowne całości; 3) selektywne porównywanie, czyli zestawianie informacji nowych z tymi nabytymi w przeszłości (por. Davidson, Sternberg, 1984).

W artykule poświęconym determinantom kompetencji szkolnych Kossowska i Schouwenburg (2000) przywołują listę dość klasycznych (pochodzących głównie z lat 70.) badań, których rezultaty potwierdziły znaczący i pozytywny wpływ intelektu na poziom funkcjonowania szkolnego. Mimo że wydaje się oczywiste, iż bardziej inteligentni uczniowie uzyskują lepsze wyniki, autorzy wielu opracowań w tym zakresie zaznaczają, że nie wszystkie osoby charakteryzują- 
ce się wysokim poziomem inteligencji dobrze radzą sobie w sytuacji szkolnej (por. Kossowska, 2004). O tym, że jednoznaczny związek między wysoką inteligencją a sukcesami edukacyjnymi nie jest regułą, świadczy choćby powszechnie obserwowany w praktyce szkolnej i w badaniach psychologicznych syndrom nieadekwatnych osiągnięć (Dyrda, 2000). Polega on na tym, że osoby wybitnie inteligentne uzyskują niskie wyniki na sprawdzianach czy egzaminach i są postrzegane jako słabi uczniowie. W przypadku tego zjawiska wysoka inteligencja nie jest wystarczającym czynnikiem psychologicznym gwarantującym sukcesy szkolne, co sugeruje, że znaczące mogą być również inne czynniki. Analizując inteligencję jako korelat sukcesu życiowego, Robert Sternberg (2001) zwrócił uwagę, że uczniowie uzdolnieni wcale nie muszą koncentrować się na nauce i osiągać wybitnych rezultatów. Mogą bowiem zajmować się zajęciami pozaszkolnymi i w tych obszarach odnosić sukcesy, zaniedbując niejako oceny szkolne.

Podobnych wniosków dostarczają badania Doroty Turskiej (2006) dotyczące poziomu inteligencji tzw. prymusów. Autorka wykazała, że najlepsi uczniowie wcale nie są najbardziej inteligentni (Turska, 2006, 2008). Badaniami objęto 300 prymusów z lubelskich szkół ponadpodstawowych oraz odpowiednio dobraną grupę uczniów osiągających niższe wyniki. Zastosowany w analizach test Ravena wykazał zaskakująco wysokie zróżnicowanie potencjału intelektualnego uczniów z najlepszymi wynikami, jak również grupy kontrolnej. Jedynie $20 \%$ prymusów uzyskało wyniki wskazujące na bardzo wysoki poziom inteligencji niewerbalnej. Co ciekawe, równie często wśród uczniów ocenianych najwyżej zdarzali się badani z nieco niższym niż przeciętny poziomem zdolności intelektualnych, ale zaobserwowano też w tej grupie wyniki określane jako „znacząco poniżej przeciętnej”. Wśród prymusów najwięcej było tych z wynikami ,przeciętnymi plus”. Badani z grupy porównawczej też reprezentowali zróżnicowany poziom inteligencji niewerbalnej mierzonej testem Ravena. Oznacza to, że wysoki potencjał intelektualny nie jest warunkiem koniecznym ani gwarantem wysokich wyników szkolnych i egzaminacyjnych.

Analogiczne rezultaty przytacza Maciej Karwowski (2004). Badaniami objął 561 uczniów warszawskich szkół średnich, w których sprawdził, jak poziom inteligencji i zdolności twórczych koreluje z ich osiągnięciami szkolnymi wyrażonymi średnią ocen. W badaniach ujawniono, że inteligencja mierzona testem Ravena wykazuje istotny, choć słaby związek z sukcesami edukacyjnymi uczniów, podobnie jak pozostałe zmienne wyjaśniające brane pod uwagę w tym badaniu. Najsilniej wyniki szkolne różnicowała płeć badanych. Dziewczynki uczyły się lepiej. Trudno jednak zakładać, że system edukacji jakkolwiek faworyzuje kobiety. Najprawdopodobniej istnieją inne cechy, które pozwalają osiągać sukcesy uczniom, bez względu na poziom zdolności poznawczych (choć niewątpliwie przy jakimś minimalnym poziomie potencjału intelektualnego).

Wydaje się jednak, że jest jeszcze pewien szczegół metodologiczny obecny w omawianych badaniach, który może mieć znaczenie dla uzyskiwanych wyni- 
ków. W większości analiz nad rolą inteligencji dla sukcesów edukacyjnych wykorzystywany jest test Ravena ze względu na szybkość zbierania danych. Mierzy on inteligencję ,płynną”, która polega na umiejętności dostrzegania abstrakcyjnych powiązań między elementami wzorów, rozumienia relacji między nimi i myślenia przez analogię. Ten rodzaj inteligencji nie jest bezpośrednio związany z nabytą wiedzą. Nie dotyczy też wprost konkretnych umiejętności kształconych w procesie edukacji, mimo że niewątpliwie stanowi podstawę ich kształtowania. Jest tak dlatego, że inteligencja płynna często bywa utożsamiana z potencjałem intelektualnym, na którego bazie rozwijają się konkretne zdolności zależne już od doświadczeń i edukacji. Wykorzystanie tej miary w badaniach może być uzasadnione w następujący sposób. Skoro badamy poziom możliwości intelektualnych, od których zależy poziom kształconych zdolności, to możliwe będzie również zaobserwowanie określonego poziomu efektów tego kształcenia (osiągnięć szkolnych). Jeśli tak nie jest, to prawdopodobnie istnieją dodatkowe czynniki, które znacząco wpływają na realizację tego potencjału w toku edukacji. Wielu autorów konkluduje, że cechy pozaintelektualne, takie jak motywacja, zainteresowania, cechy osobowości determinujące zaangażowanie, pracowitość czy systematyczność, mogą mieć większe znaczenie, niż pierwotnie zakładano (Kossowska, Schouwenburg, 2000; Karwowski, 2004; Turska, 2006; Boryszewska, 2008). Wygląda na to, że powszechnie znane powiedzenie „Zdolny, ale leniwy” ma swoje naukowe uzasadnienie.

Nęcka, autor formalnej teorii inteligencji oraz wielu badań i opracowań w tym zakresie, wskazuje, że ,korelacja między ilorazem inteligencji a osiągnięciami szkolnymi jest dość słaba, choć pozytywna" (Nęcka, 2000, s. 750). Przywołując analizy Ackermana (1994, za: Nęcka, 2000) sugeruje, że być może uzyskiwane w badaniach niejednoznaczne wyniki dotyczące związku między wysoką inteligencją a sukcesami szkolnymi wynikają ze specyfiki prowadzonych badań. Zwraca uwagę na to, że w sytuacji testu inteligencji badani są z reguły zmotywowani do zaprezentowania swoich maksymalnych możliwości, podczas gdy motywacja ta nie jest tak wysoka w codziennym funkcjonowaniu szkolnym. Necka (2000) postuluje, że to właśnie niespójność pomiędzy maksymalnym i typowym działaniem intelektualnym sprawia, że testy inteligencji nie są dobrym predyktorem osiągnięć szkolnych. Teza ta nie wprost ujawnia również rolę czynników pozaintelektualnych, takich jak motywacja, które mogą mieć znaczenie dla sukcesów edukacyjnych.

Jest jeszcze jedna ważna obserwacja istotna dla pełnego zrozumienia związku pomiędzy inteligencją a osiągnięciami szkolnymi. Analizując wyniki badań przeprowadzonych na populacji uczniów szkół wyższych, Nęcka (2000) zwraca uwagę na to, że poziom zdolności poznawczych studenta odgrywa coraz mniejszą rolę w determinowaniu poziomu jego osiągnięć na uczelni wraz z upływem kolejnych lat studiów. Badania porównawcze prowadzone na populacjach uczniów 
i studentów wyższych uczelni wykazują, że siła związku pomiędzy inteligencją a sukcesami edukacyjnymi zmienia się wraz z grupami wiekowymi, których dotyczy, a na wyższych poziomach edukacji w zasadzie zanika (Chamorro-Premuzic, Furnham, 2003; Furnham, Chamorro-Premuniz, 2004). W świetle tych analiz wydaje się, że powodzenie na coraz wyższych poziomach edukacji nie zależy już od inteligencji ogólnej (jej poziom jest jednak zbliżony i co najmniej przeciętny u większości studentów), a coraz bardziej od innych czynników - motywacyjnych, osobowościowych czy związanych z indywidualnymi zainteresowaniami i predyspozycjami (por. Furnham, Chamorro-Premuniz, 2004; Vedel, 2014; Roth i in., 2015; Poropat, 2016).

Badania przeprowadzone na populacji studentów wykazały, że poziom inteligencji wyjaśnia zaledwie kilka procent ogólnej wariancji osiągnięć edukacyjnych w tej grupie badanych (Kossowska, Schouwenburg, 2000; Chamorro-Premuzic, Furnham, 2003; Furnham, Chamorro-Premuniz, 2004; Roth i in., 2015). O ile przeciętny poziom inteligencji nie różni się tak bardzo między studentami w obrębie jednego kierunku, o tyle struktura zdolności poznawczych u studentów różnych kierunków w sposób oczywisty jest już zróżnicowana. Badania nad normalizacją baterii testów APIS-Z wykazały, że studenci różnych kierunków studiów różnią się w zakresie poszczególnych rodzajów zdolności mierzonych tym narzędziem (Matczak, Jaworowska, Ciechanowicz, Stańczak, 1995). Humaniści osiągają istotnie wyższe wyniki w testach zdolności werbalnych niż w tych mierzących zdolności wzrokowo-przestrzenne, w których z kolei przodują studenci kierunków technicznych. Badani studiujący kierunki ścisłe okazali się wyróżniać w zakresie zdolności abstrakcyjno-logicznych. Studenci kierunków artystycznych uzyskiwali z kolei najwyższe wyniki w podtestach, w których uwzględnia się płynność myślenia (będącą składnikiem zdolności twórczych). Zaobserwowane zróżnicowania nie są zaskakujące, ponieważ można przypuszczać, że wybór konkretnego kierunku studiów i powodzenie na egzaminach zależą od predyspozycji kandydatów. Co więcej, studiowanie na określonych kierunkach przyczynia się do dalszego rozwoju określonych zdolności (Piotrowska, 1992).

Podsumowując zaprezentowane rozważania dotyczące roli inteligencji jako determinanty sukcesów szkolnych, można sformułować następujący wniosek. Inteligencja ogólna stanowi potencjał intelektualny, na którego bazie rozwija się wiedza i konkretne umiejętności oceniane w szkole czy podczas egzaminów. Ogólne możliwości poznawcze uczniów są silniejszą determinantą ich wyników na wczesnych szczeblach edukacji. W późniejszych etapach kształcenia wraz ze wzrostem wymagań i ilością zadań edukacyjnych do zrealizowania ogólny poziom inteligencji ma coraz mniejsze znaczenie. Istotna staje się wówczas struktura inteligencji oraz to, które zdolności dominują, stanowiąc rodzaj predyspozycji do studiowania określonych kierunków. Znaczenia nabierają również czynniki 
pozaintelektualne, jak np. motywacja, inteligencja emocjonalna, umiejętności zarządzania czasem, zainteresowania, ale przede wszystkim cechy osobowości (por. Vedel, 2014; Poropat, 2016).

\section{OSOBOWOŚĆ}

Analizy znaczenia zmiennych osobowościowych dla osiągnięć szkolnych zainicjowano już dość dawno. Badania przeprowadzone w latach 60. przez Raymonda Cattella (1965, za: Kossowska, 2004) pokazały, że studenci wyselekcjonowani pod względem kryteriów inteligencji i osobowości osiągali lepsze wyniki na studiach niż ci, którzy zostali przyjęci wyłącznie na podstawie testów zdolności poznawczych. Przez lata badacze poszukiwali osobowościowych uwarunkowań sukcesów szkolnych, rozważając znaczenie czynników wolicjonalnych czy wytrwałości (por. przegląd w: Kossowska, 2004). Jednak dopiero wprowadzenie pięcioczynnikowego modelu przez Paula T. Costę i Roberta McCrae (1992) zainspirowało systematyczne badania w tym zakresie.

W tej części opracowania omówiono wyniki i wnioski z analiz poświęconych roli czynników wchodzących w skład tzw. Wiekiej Piątki (Costa, McCrae, 1992), tj. ekstrawersji, neurotyczności, ugodowości, otwartości na doświadczenia i sumienności, dla sukcesów szkolnych i egzaminacyjnych. Wszystkie przywołane wyniki pochodzą $\mathrm{z}$ badań prowadzonych $\mathrm{w}$ tym samym paradygmacie na różnych grupach uczestników, pochodzących z różnych stron świata. Badani wypełniają odpowiednią, zaadaptowaną do danej kultury wersję skali NEO-FFI (por. polską adaptację tego narzędzia: Zawadzki, Strelau, Szczepaniak, Śliwińska, 1998) mierzącą wszystkie pięć czynników. Wyniki w zakresie mierzonych cech wchodzących w skład Wielkiej Piątki zestawiane są z osiągnięciami szkolnymi operacjonalizowanymi poprzez średnie ocen szkolnych, wyniki różnych egzaminów i testów czy oceny wykładowców. W efekcie określana jest korelacja pomiędzy konkretnymi cechami osobowości a osiągnięciami szkolnymi.

Ekstrawersja jest w modelu Wielkiej Piątki rozumiana jako cecha odnosząca się do ilości interakcji społecznych, poziomu aktywności i energii. Charakteryzuje się towarzyskością, asertywnością i ekspresyjnością. Badania analizujące znaczenie tej cechy dla osiągnięć szkolnych ujawniają niejednoznaczne zależności (por. Kossowska, Schouwenburg, 2000; Akomolafe, 2013), choć większość wskazuje na negatywną korelację ekstrawersji z sukcesami edukacyjnymi (np. Furnham, Chamorro-Premuzic, McDougall, 2003; Furnham, Chamorro-Premuzic, 2004). Mimo że obserwowane w badaniach efekty okazały się sprzeczne z początkowymi oczekiwaniami badaczy, którzy zakładali, że ekstrawertycy będą lepiej radzić sobie z wyzwaniami szkolnymi niż introwertycy (por. Kossowska, Schouwenburg, 2000), to można je wyjaśnić specyfiką funkcjonowania ekstrawertyków - ich wigor i towarzyskość nie sprzyjają realizacji zadań szkolnych, 
które wymagają skupienia. Co więcej, szerokie zainteresowania i kontakty społeczne sprawiają, że ekstrawertycy w znacznie większej mierze niż introwertycy angażują się w aktywności pozaszkolne (Eysenck, 1992).

Neurotyczność, kolejna z cech w modelu Costy i McCrae (1992), charakteryzuje niezrównoważenie emocjonalne, skłonność do przeżywania emocji negatywnych oraz mała odporność na stres. Takie cechy nie sprzyjają sprawnej realizacji zadań szkolnych ani wysokim wynikom egzaminacyjnym. Już w latach 80 . Charles D. Spielberger (1980) wykazał, że lęk i związane z nim napięcie wpływa negatywnie na efektywność uczenia się. Analogicznie większość obecnych w literaturze badań wykazujących istotne zróżnicowanie osiągnięć szkolnych ze względu na poziom neurotyczności ujawnia negatywne korelacje (Chamorro-Premuzic, Furnham, 2003; Akomolafe, 2013; Vedel, 2014).

Kolejną cechą osobowości, która wykazuje pewne związki z sukcesami edukacyjnymi, jest otwartość na doświadczenie. Cecha ta oznacza ciekawość poznawczą oraz pozytywne podejście do nowości i różnorodności. Jest dość ściśle powiązana z myśleniem twórczym, wydaje się zatem sprzyjać realizacji różnorodnych zadań szkolnych. Jednak wyniki analiz dotyczących tej cechy nie są jednoznaczne. Z jednej strony badania wykazują pozytywne związki pomiędzy otwartością a osiągnięciami szkolnymi (Kossowska, Schouwenburg, 2000; Chamorro-Premuzic, Furnham, 2008; Akomolafe, 2013), z drugiej zaś brak istotnych korelacji między tymi zmiennymi jest dość powszechnie odnotowywany w badaniach (por. Conard, 2006; Akomolafe, 2013; Vedel, 2014). Wydaje się, że u podstaw tych niespójności może leżeć rodzaj zadania, którym mierzone są sukcesy szkolne. Jeśli te wskaźniki tworzone są w oparciu o zadania wymagające twórczego myślenia, otwartości na nowości i niekonwencjonalnego podejścia, to otwartość na doświadczenia jako cecha osobowości będzie sprzyjać generowaniu właściwych lub wysoko ocenianych odpowiedzi. Zadania, których rozwiązanie tego nie wymaga, nie będą różnić się jakością wygenerowanych rezultatów u badanych z wysoką lub niską otwartością na doświadczenia.

Ugodowość jest cechą osobowości opisującą nastawienie jednostki do ludzi. Oznacza skłonność do dostosowywania się do różnych sytuacji społecznych i wymagań, ufną, przyjacielską i współpracującą postawę wobec otoczenia. Niska ugodowość wiąże się z wrogością i brakiem zaufania do innych ludzi. Jest to cecha, w przypadku której wyniki badań nad jej związkami z sukcesami edukacyjnymi są najmniej jednoznaczne. Maureen C. Conrad (2006) wykazała pozytywne korelacje ugodowości z osiągnięciami szkolnymi, uzasadniając obserwowane związki tym, że ugodowi studenci lepiej odczytują i odpowiadają na wymagania nauczyciela i w efekcie uzyskują lepsze stopnie. Z kolei Kossowska i Schouwenburg (2000), prowadząc badania na populacjach międzynarodowych, nie odnotowali istotnych powiązań między tymi zmiennymi.

Najbardziej jednoznacznie z czynników Wielkiej Piątki z sukcesami edukacyjnymi koreluje sumienność. Jest to cecha odnosząca się do zaangażowania, wy- 
trwałości i motywacji w realizacji zadań zorientowanych na cel. Jej pozytywny związek z osiągnięciami szkolnymi jest regularnie wykazywany w badaniach (zob. m.in. Boryszewska, 2008; Czerniawska, Zawadzki, 2010; Akomolafe, 2013; Vedel, 2014; Poropat, 2016; Kamińska, 2017). Uczniowie i studenci charakteryzujący się wysokim natężeniem tej cechy są systematyczni, przygotowani do zajęć, wytrwale pracują oraz z determinacją realizują postawione przed nimi zadania edukacyjne. Pogłębione analizy prowadzone przez Kossowską i Schouwenburga (2000) wykazały, że sumienność związana jest z dyscypliną pracy, przemyślanymi i sprzyjającymi efektywności strategiami uczenia się, ale również z dociekliwością i zadawaniem pytań oraz strukturalizowaniem odpowiedzi. W prowadzonych przez tę parę badaczy analizach (Kossowska, Schouwenburg, 2000; por. Kossowska, 2004) to właśnie sumienność i jej związki z dyscypliną oraz ze strategiami głębokiego przetwarzania informacji znacznie silniej niż inteligencja wyjaśniały zmienność poziomu osiągnięć szkolnych.

\section{ZAKOŃCZENIE}

Podsumowując rozważania, można odpowiedzieć na zadane na wstępie pytanie, czy IQ się liczy, w następujący sposób. Jako determinanta osiągnięć szkolnych inteligencja się liczy, ale najprawdopodobniej znacznie mniej niż się powszechnie wydaje. Co więcej, jej znaczenie zmienia się w zależności od etapu edukacyjnego oraz tego, czy bierzemy pod uwagę ogólny poziom intelektualny czy też strukturę zdolności poznawczych jednostki. W przypadku inteligencji ogólnej ma ona zdecydowanie pozytywny wpływ na wczesnych poziomach kształcenia. Wtedy potencjał intelektualny decyduje o tym, jak szybko i efektywnie nabywamy poszczególne umiejętności (czytania, pisania, liczenia itp.), a zadania edukacyjne nie są jeszcze bardzo złożone i specyficzne. Na wyższych poziomach kształcenia rozwijane umiejętności są coraz bardziej związane ze szczególnymi rodzajami zdolności intelektualnych, np. zadania ze stereometrii wymagają zdolności wzrokowo-przestrzennych, a pisanie esejów ewaluacyjnych czy porównawczych - płynności słownej i zdolności analitycznych. Znaczenia nabiera wówczas to, czy profil specyficznych zdolności jednostki jest spójny z podejmowanymi zadaniami edukacyjnymi czy też nie, a uogólniony poziom inteligencji przestaje być czynnikiem istotnie różnicującym wyniki (choć zapewne wciąż jest pomocny). To jednak, czy potencjał zostanie wykorzystany, zależy już od czynników osobowościowych: wytrwałości, systematyczności oraz motywacji w realizacji zadań. Można więc powiedzieć, że czasem sumienność liczy się bardziej niż IQ. 


\section{BIBLIOGRAFIA}

Akomolafe, M.J. (2013). Personality Characteristics as Predictors of Academic Performance of Secondary School Students. Mediterranean Journal of Social Sciences, 4(2), 656-664.

Boryszewska, J.K. (2008). Źródła sukcesu szkolnego młodzieży licealnej. Kraków: Oficyna Wydawnicza Impuls.

Chamorro-Premuzic, T., Furnham, A. (2003). Personality traits and academic examination performance. European Journal of Personality, 17(3), 237-250.

DOI: https://doi.org/10.1002/per.473

Chamorro-Premuzic, T., Furnham, A. (2008). Personality, intelligence, and approaches to learning as predictors of academic performance. Personality and Individual Differences, 44(7), 15961603. DOI: https://doi.org/10.1016/j.paid.2008.01.003

Conard, M.A. (2006). Aptitude is not enough: How personality and behavior predict academic performance. Journal of Research in Personality, 40(3), 339-346.

DOI: https://doi.org/10.1016/j.jrp.2004.10.003

Conrad, N., Party, M.W. (2012). Conscientiousness and Academic Performance: A Mediational Analysis. International Journal for the Scholarship of Teaching and Learning, 6(1), 1-14. DOI: https://doi.org/10.20429/ijsotl.2012.060108

Costa, P.T., McCrae, R.R. (1992). Four ways five factors are basic. Personality and Individual Differences, 13(6), 653-665. DOI: https://doi.org/10.1016/0191-8869(92)90236-I

Czerniawska, E., Zawadzki, B. (2010). Aktywność strategiczna jako czynnik pośredniczący w relacji osobowość - osiągnięcia w nauce. W: A.E. Sękowski, W. Klinkosz (red.), Zdolności człowieka w ujęciu współczesnej psychologii (s. 15-31). Lublin: Towarzystwo Naukowe KUL.

Davidson, J., Sternberg, R. (1984). The role of insight in intellectual giftedness. Gifted Child Quarterly, 28(2), 58-64. DOI: https://doi.org/10.1177/001698628402800203

Dyrda, B. (2000). Syndrom nieadekwatnych osiagnięć jako niepowodzenie szkolne uczniów zdolnych. Diagnoza i terapia. Kraków: Oficyna Wydawnicza Impuls.

Eysenck, H.J. (1992). Personality and education: The influence of extraversion, neuroticism and psychoticism. Zeitschrift für Pädagogische Psychologie, 6, 133-144.

Furnham, A., Chamorro-Premuzic, T., McDougall, F. (2003). Personality, cognitive ability, and beliefs about intelligence as predictors of academic performance. Learning and Individual Differences, 14(1), 49-66. DOI: https://doi.org/10.1016/j.lindif.2003.08.002

Furnham, A., Chamorro-Premuzic, T. (2004). Personality and intelligence as predictors of statistics examination grades. Personality and Individual Differences, 37(5), 943-955.

DOI: https://doi.org/10.1016/j.paid.2003.10.016

Kamińska, A. (2017). Psychologiczne i społeczne uwarunkowania osiągnięć osób zdolnych - analiza i wskazówki dla nauczycieli i rodziców pracujących z osobami zdolnymi. Studia Paedagogica Ignatiana, 20(3), 101-118. DOI: https://doi.org/10.12775/SPI.2017.3.006

Karwowski, M. (2004). Inteligencja ,,akademicka”, emocjonalna i zdolności twórcze uczniów o różnych osiągnięciach szkolnych. Studia Psychologica UKSW, (5), 103-115.

Kossowska, M. (2004). Psychologiczne uwarunkowania osiągnięć szkolnych. W: A.E. Sękowski (red.), Psychologia zdolności. Współczesne kierunki badań (s. 47-62). Warszawa: PWN.

Kossowska, M., Schouwenburg, H.C. (2000). Inteligencja, osobowość i osiągnięcia szkolne. Przeglad Psychologiczny, 43(1), 81-101.

Matczak, A., Jaworowska, A., Ciechanowicz, A., Stańczak, J. (1995). Bateria testów APIS-Z. Warszawa: Pracownia Testów Psychologicznych PTP.

Nęcka, E. (2000). Inteligencja. W: J. Strelau (red.), Psychologia. Podręcznik akademicki. Psychologia ogólna (T. 2; s. 721-760). Gdańsk: GWP.

Nęcka, E. (2005). Inteligencja: geneza, struktura, funkcje. Gdańsk: GWP. 
Nęcka, E. (2012). Czy IQ się liczy? Wykład wygłoszony na spotkaniu „Granice Nauki” w ramach Copernicus Festiwal. Pobrane z: www.copernicusfestival.com/wydarzenia/edward-necka-czyiq-sie-liczy-35559? language $=p l$ (dostęp: 10.03.2020).

Piotrowska, A. (1992). Różnicowanie się inteligencji ogólnej w zależności od profilu kształcenia. Psychologia Wychowawcza, (5), 326-336.

Poropat, A.E. (2016). Beyond the shadow: The role of personality and temperament in learning. W: L. Corno, E.M. Anderman (eds.), Handbook of Educational Psychology (s. 172-185). New York: Routledge.

Roth, B., Becker, N., Romeyke, S., Schäfer, S., Domnick, F., Spinath, F.M. (2015). Intelligence and school grades: A meta-analysis. Intelligence, 53, 118-137.

DOI: https://doi.org/10.1016/j.intell.2015.09.002

Spielberger, Ch.D. (1980). Test Anxiety Inventory: Preliminary Professional Manual. Palo Alto: Consulting Psychologists Press.

Sternberg, R.J. (1985). Beyond IQ: A Triarchic Theory of Human Intelligence. Cambridge: Cambridge University Press.

Sternberg, R.J. (2001). Próba weryfikacji teorii inteligencji sprzyjającej powodzeniu życiowemu poprzez operacje konwergencyjne. Przeglad Psychologiczny, 44(4), 375-403.

Turska, D. (2006). Prymusi o niskim poziomie zdolności intelektualnych - w poszukiwaniu przyczyn ocen ,za wysokich”. Psychologia Rozwojowa, 11(1), 31-45.

Turska, D. (2008). Niezdolny prymus? W poszukiwaniu wyjaśnienia pozornego absurdu. Psychologia w Szkole, (2), 87-93.

Vedel, A. (2014). The Big Five and tertiary academic performance: A systematic review and metaanalysis. Personality and Individual Differences, 71, 66-76.

DOI: https://doi.org/10.1016/j.paid.2014.07.011

Zawadzki, B., Strelau, J., Szczepaniak, P., Śliwińska, M. (1998). NEO-FFI. Inwentarz Osobowości Paula Costy i Roberta McCrae. Warszawa: Pracownia Testów Psychologicznych PTP.

\section{SUMMARY}

The article discusses the issue of intellectual and personality factors affecting school performance and exam results. Arguments for the claim that cognitive abilities condition academic achievements were analyzed. In result it was concluded that intelligence constitute a kind of potential which significance depends on education level - stronger relations are observed in case of early stages of education. At the higher ones more significant is not the level of general intelligence but particular kind of intellectual abilities and their relevance to the exam task. Moreover analysis demonstrated that realization of intellectual potential is not given as such but depends on work and persistence determined by personality factors such as conscientiousness included in the so-called Big Five model.

Keywords: intelligence; personality; the Big Five; conscientiousness; academic achievements 